\title{
Experience with migrants on Balkan Route from the Field Hospital on the Slovenian-Croatian Border
}

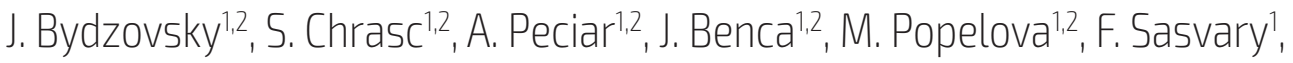 \\ A. Matel', M. Cernicky², D. Kalatova',2, Z. Nevolna,,2, J. Kafkova,', C. Zollerova 1,2, \\ M. Kolibab,2, S. Putekova ${ }^{3}$, J. Martinkova3, G. Mikolasova 1,2, M. Komlosi',2
}

Original Articles

1 St. John Nepomuk Neumann Institute SEU Pribram, Czech Republic

2 St. Elizabeth University Field Hospital Dobova, Slovenia

3 Trnava University School of Health Slovenia/Croatia Border Check-point

\section{Correspondence to:}

St. Elizabeth Univ. Laboratory of Molecular Biology, Nám. 1. Mája č. 1, 810 00, Bratislava, Slovakia

\section{Reviewers:}

J. Suvada

St. Charles Foucauld Health Center, St. Elisabeth University, Beirut, Lebanon

G. Lezcano

University of California, San Francisco, USA

\section{Key words:}

Migrants, Epidemics, Balkan Route.

\section{Key message:}

Few transmissible diseases in migrants from Greece to Central Europe.

CSWHI 2016; 7(3): 32-34; 10.22359/cswhi_7_3_08 @ 2016 Clinical Social Work and Health Intervention

\section{Abstract:}

Aim of the Study: Balkan Route for Syrian and Iraqi refugees started on September 6, 2015 and ended on March 2, 2016 and it took 7 months for 1,190,000 people to migrate from those war and conflict areas. The aim of the study was to assess the spectrum of diseases in the population of migrants in 2015/2016.

Patients and Methods: A total of 6,142 refugees from Iraq, Syria and Afghanistan visited our field hospital in Dobova on the Slovenian-Croatian border; 4,111 were children. The spectrum of diagnoses and screening tests in suspect cases were assessed.

Results: Majority of the patients did not suffer from any tropical disease; no new case of TB was detected; all the tests for HIV, Hepatitis 
$\mathrm{B}$ and $\mathrm{C}$ were negative. The spectrum of disease was similar to the one of the host country, i.e. depression, diarrhea, respiratory tract infections and chronic diseases, such as asthma and coronary artery disease in the elderly were common.

Conclusion: Refugees migrating through the Balkan Route from Syria, Iraq and Afghanistan though Turkey and Greece have very similar epidemiological characteristics as the host population. No outbreaks and no sporadic transmissible diseases were reported in the period from September 2015 till March 2016 in this group of migrants from the Middle East.

\section{Introduction}

The refugee crisis in European Union (EU) started with the so-called African-Mediterranean Route from Libya to Italy and Malta, where since 2004, every year in total of 250,000 migrants, most of them being "economic" migrants, crossed the Mediterranean Sea to European Union (i.e. 3 million migrants in total). The Balkan Route for Syrian and Iraqi refugees started on September 6, 2015 and ended on March 2, 2016 and it took 7 months for 1,190,000 people to migrate from those war and conflict areas. (1-2). The aim of the study was to assess the spectrum of diseases in the population of migrants in 2015/2016.

\section{Patients and Methods}

Among about 150,000 migrants who took the Route from September $6^{\text {th }}$ until March $6^{\text {th }}$ when the transports through Croatia, Serbia and Macedonia were suspended 6,142 migrants sought medical help at the St. Elisabeth Field Hospital in Dobova on Slovenian-Croatian Border. The Field Hospital included 4 physicians, 4 rescue staff, 2 nurses, 4 social workers, drivers and logisticians. Medicines and tests for screening (HIV, Hepatitis $\mathrm{B}$ and $\mathrm{C}$, swabs for rectal and respiratory pathogens) were provided by St. Elisabeth Laboratory of Molecular Diagnostics.

\section{Results and Discussion}

Table 1 presents the commonest diseases diagnosed and presented to the Slovak staff from September 6, 2015 till March 2, 2016. Among the transmissible diseases were 626 cases scabies; 299 cases lower RTI (Respiratory Tract Infections) with reported (predominantly pediatric pneumonia); 632 cases upper RTI (both in children and adults) reported. No case of TB or other epidemiologically important diseases such as typhoid fever, Hepatitis A and B , HIV typical for such regions was reported. The majority of sick refugees suffered from a chronic disease related to long-term conflict, war, displacement such as asthma, hypertension, depression, which were responsible for $>50 \%$ of all visits at the Out-patient Department of the Field Hospital of the St. Elisabeth Tropic Team in Dobova on Slovenian-Croatian Border. Similarly to our patients in Dohuk and Erbil (refugees from Mosul to Kurdistan) (2) or Hegyeshalom-Nickelsdorf (HU-AU) checkpoint with 612,00 migrants crossing to Austria, where no outbreak of transmissible/ tropical/infectious disease was observed (1-4).

\section{Conclusion}

The Balkan Route for Syrian and Iraqi refugees started on September 6, 2015 and ended on March 2, 2016 and it took 7 months for 1,190,000 people to migrate from those war and conflict areas. The aim of the study was to assess the spectrum of diseases in the population of migrants in 2015/2016. A total of 6,142 refugees from Iraq, Syria and Afghanistan visited our field hospital in Dobova on Slovenian-Croatian border; 
4,111 were children. The spectrum of diagnoses and screening tests in suspect cases were assessed. The majority of the patients did not suffer from any tropical disease; no new case of TB was detected; all the tests for HIV, Hepatitis B and C were negative. The spectrum of disease was similar to the host country, i.e. depression, diarrhea, respiratory tract infections and chronic diseases, such as asthma and coronary artery disease in the elderly were common. Refugees migrating through the Balkan Route from Syria, Iraq and Afghanistan though Turkey and Greece have very similar epidemiological characteristics as the host population. No outbreaks and no sporadic transmissible diseases were reported in the period from September 2015 till March 2016 in this group of migrants from the Middle East.
2. ALJOUNI, KAMEL et al:: Refugees in the eastern Mediterranean region. The Lancet, Volume 386, Issue 10012, 2476-2477

3. WICZMANDYOVA D, MURGOVA A, The life of diabetics, life with diabetes, Book.Clear Michalovce ISBN 978-809711629255.2012 , pp 67.

4. WICZMANDYOVA, D, TKACOVA, L, MURGOVA, M: Proceedings Slov. Med. Univ.: The Socio Economic aspect of Migrations, ISBN 978-80-89352-47-0, pp 62-70

5. SUN YS, ZHAO XY, ZHANG BK, JIANG JF, LU HJ, CAO YX, WU GZ, QIAN J, SUN Y, ZENG YJ: Practices and thinking of laboratory detection in the aid to West Africa to fight against Ebola. Bratislava Medical Journal Vol.117, No.5, p.254-257, 2016. doi:10.4149/BLL_2016_049.

Tab 1. Commonest diseases among 6,142 refugees form Middle and Far East to EU via Balkan Route seen from September $6^{\text {th }}, 2015$ till March $2^{\text {nd }}, 2016$ In Dobova Field Hospital.

\begin{tabular}{|l|c|}
\hline \multicolumn{1}{|c|}{ Diagnosis } & Number of patients \\
\hline Upper RTIs & 632 \\
\hline Lower RTIs & 299 \\
\hline Congelatio & 201 \\
\hline Skin parasites (scabies) & 626 \\
\hline Coronary artery disease & 716 \\
\hline Hypertension & 1,346 \\
\hline Asthma & 614 \\
\hline Diabetes mellitus & 299 \\
\hline Depression & 1,106 \\
\hline Total number of patients & 6,142 \\
\hline
\end{tabular}

\section{References}

1. ESCOBIO, FAVILA et al:: Health assistance of displaced people along the Balkan route. The Lancet, Volume 386 , Issue 10012,2475
6. SILHAROVA B, SUVADA J, FRANEKOVA M, NOGE A, MIKOLASOVA G: Malaria in hyperendemic region, Neuroendocrinology Letters 34, 2013, s1 38-43 